Check for updates

Cite this: RSC Adv., 2017, 7, 30199

Received 24th March 2017 Accepted 3rd June 2017

DOI: $10.1039 / c 7 r a 03439 c$

rsc.li/rsc-advances

\section{A mesoporous titanium glycolate with exceptional adsorption capacity to remove multiple heavy metal ions in water +}

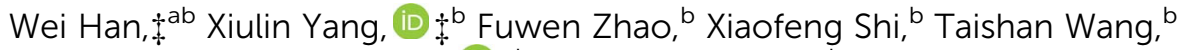 \\ Xiangdong Zhang, ${ }^{* a}$ Li Jiang (D) ${ }^{* b}$ and Chunru Wang ${ }^{b}$
}

\begin{abstract}
A facile, green strategy is explored to obtain mesoporous titanium glycolate $\left(\mathrm{Ti}\left(\mathrm{OCH}_{2} \mathrm{CH}_{2} \mathrm{O}\right)_{2}\right)$ via a one-pot hydrothermal reaction. The mesoporous $\mathrm{Ti}\left(\mathrm{OCH}_{2} \mathrm{CH}_{2} \mathrm{O}\right)_{2}$ nanomaterials take on a three-dimensional $\mathrm{V}$-type stripe structure with a specific surface area of $246.5 \mathrm{~m}^{2} \mathrm{~g}^{-1}$ and present an excellent adsorption capacity of toxic heavy metal ions in aqueous solution, $225.73 \mathrm{mg} \mathrm{g}^{-1}$ for $\mathrm{Pb}(\Perp), 131.93 \mathrm{mg} \mathrm{g}^{-1}$ for As(v) and $156.01 \mathrm{mg} \mathrm{g}^{-1}$ for As(III) with fast adsorption rates. The removal mechanism was found to derive from the electrostatic interaction or coordination interaction between $\mathrm{Ti}\left(\mathrm{OCH}_{2} \mathrm{CH}_{2} \mathrm{O}\right)_{2}$ and heavy metal ions in aqueous solution since the mesoporous materials display a $\mathrm{pH}$-dependent effect for arsenic removal.
\end{abstract}

\section{Introduction}

Drinking-water pollution induced by heavy metal ions is a serious threat for human health all over the world because of their serious health-toxic and non-biodegradable properties., ${ }^{\mathbf{1 , 2}}$ For example, lead can accumulate in the apatite structure of bone to obstruct biosynthesis of heme as well as inhibit zinc enzymes and protein synthesis; ${ }^{3}$ Arsenic, being in the form of arsenite As(III) or arsenate As(v) in aqueous solution, may cause skin, lung or bladder cancer. ${ }^{4-6}$ However, because the toxic heavy metals are usually in low concentration and co-exist with nontoxic metal ions such as $\mathrm{Fe}, \mathrm{Ca}, \mathrm{Na}$ etc., the high efficiency and selective removal of these contaminants from drinking water remains a challenge.

Recently, the rapid development of nanoscience and nanotechnology has greatly promoted drinking water treatment techniques by using nanomaterial adsorbents to remove the heavy metal contaminants. As is well known, nanomaterials usually possess large specific surface area and abundant active sites, ${ }^{7}$ which are expected to selectively absorb some specific heavy metals. For example, the nanomaterials based on titanium, iron and aluminum compounds or complexes ${ }^{8-10}$ have been observed to efficiently absorb $\mathrm{Pb}$ or As with remaining the innocuous metal ions unchanged.

${ }^{a}$ College of Chemistry, Liaoning University, Shenyang 110036, PR China. E-mail: xdzhang@lnu.edu.cn

${ }^{b}$ Beijing National Laboratory for Molecular Sciences, CAS Research/Education Center for Excellence in Molecular Sciences, Institute of Chemistry, Chinese Academy of Sciences, Beijing 100190, China. E-mail: jiangli@iccas.ac.cn

$\dagger$ Electronic supplementary information (ESI) available. See DOI: 10.1039/c7ra03439c

† W. H., X. L. Y. contributed equally.
In order to completely remove heavy metal contaminants, it is crucial to make clear both the usual chemical form of heavy metals in drinking water and how they interact with the applied nanomaterials. For most heavy metals such as $\mathrm{Hg}, \mathrm{Pb}, \mathrm{Tl}$ etc., a simple electrostatic absorption by some strong electronegative nanomaterials would suffice since they exist only in metal cationic form in water. However, some other toxic heavy metal contaminants such as As, Se, Te, etc., may have various chemical forms depending on the $\mathrm{pH}$ values in water. For example, arsenate exists as oxyanions $\left(\mathrm{H}_{2} \mathrm{AsO}_{4}{ }^{-}\right.$or $\left.\mathrm{HAsO}_{4}{ }^{2-}\right)$ in $\mathrm{pH}$ ranging from 2 to 12 , while arsenite remains as neutral molecular species $\left(\mathrm{H}_{3} \mathrm{AsO}_{3}\right)$ at $\mathrm{pH}<9.2 .{ }^{11,12}$ In general, most nanomaterials composed of metal oxides or hydroxides are positive-charged when the $\mathrm{pH}$ value being lower than the isoelectric point, so they may effectively remove the negativecharged As(v) ions by electrostatic adsorption, but these nanomaterials are difficult to remove the neutral As(III) species. ${ }^{13,14}$

In order to improve the removal efficiency of As(III), it has been suggested to chemically transfer the charge state of As from $\mathrm{As}(\mathrm{III})$ to $\mathrm{As}(\mathrm{v})$ before the treatment, ${ }^{\mathbf{1 5 - 1 7}}$ but this technique is either too complicated or kinetically too slow to be available. Undoubtedly, it would be perfect if an adsorbent can be developed to remove simultaneously both As(v) and As(III) without any additional oxidation process, which would not only simplify the water treatment procedure but also reduce the cost of water treatment to a great degree. ${ }^{4}$

To realize the simultaneous removal of As(v) and As(III), one way is to design a composite nanomaterial in which one part can adsorb the cationic heavy metals and the other part is able to adsorb the anionic ones. ${ }^{18}$ Up to now, unfortunately, such composite adsorbents are unavailable in application. Another way is to develop a material that can adsorb both metal cations and metal-containing anions in the meantime. Recently, several 
reports have shown the possibility of this technique. For example, nanoscale zero-valent iron and goethite (a-FeOOH) showed fast uptake rate and high adsorption capacity for multiple heavy metal ions simultaneously, ${ }^{19}$ and nanomaterials based on titanium compounds such as mesoporous titania beads, ${ }^{8}$ titanate nanobelts ${ }^{20}$ and titanate nanoflowers, ${ }^{21}$ also revealed potential applications in the heavy metal ions removal. However, some disadvantages of these materials, like low yields, complicated preparation processes, instability of iron-based nanomaterials and insufficient adsorption capacity of the titanium-based materials, largely limited their large-scale application in the practical drinking-water treatments.

In this context, we reported a new titanium glycolate nanomaterial of which three-dimensional V-type strip structure can not only absorb the heavy metal cations but also remove the heavy metal-containing anions simultaneously. Moreover, this material was able to be obtained using a very facile one-pot hydrothermal method, and expected to have practical applications in drinking water treatments due to its low-cost and environmentally friendly features.

\section{Experimental}

\section{Materials}

All chemical reagents used in this experiment were of analytical grade. Lead nitrate $\left(\mathrm{Pb}\left(\mathrm{NO}_{3}\right)_{2}\right)$, sodium hydrogen arsenate heptahydrate $\left(\mathrm{Na}_{2} \mathrm{HAsO}_{4} \cdot 7 \mathrm{H}_{2} \mathrm{O}\right)$, sodium arsenite $\left(\mathrm{NaAsO}_{2}\right)$, tetrabutyl orthotitanate $\left(\mathrm{Ti}\left(\mathrm{OC}_{4} \mathrm{H}_{9}\right)_{4}\right)$, ethylene glycol $\left(\mathrm{HOCH}_{2}\right.$ $\left.\mathrm{CH}_{2} \mathrm{OH}\right)$, hydrochloric acid $(\mathrm{HCl})$, sodium hydroxide $(\mathrm{NaOH})$ and ethanol were procured commercially and were used as received without further purification.

\section{Synthesis of titanium glycolate}

In a typical synthesis, $0.5 \mathrm{~mL}$ of $\mathrm{Ti}\left(\mathrm{OC}_{4} \mathrm{H}_{9}\right)_{4}$ was dissolved in 60 $\mathrm{mL}$ of $\mathrm{HOCH}_{2} \mathrm{CH}_{2} \mathrm{OH}$ and stirred at room temperature until a clear solution was formed, then the solution was transferred into a $100 \mathrm{~mL}$ Teflon-lined autoclave and heated up at $160{ }^{\circ} \mathrm{C}$ under vigorous stirring for $8 \mathrm{~h}$. After cooling to room temperature naturally, the solid precipitate was collected through a PTFE membrane (pore size: $0.22 \mu \mathrm{m}$ ), and repeatedly washed with double-distilled water and ethanol several times. The obtained products were dried in a vacuum oven at $70{ }^{\circ} \mathrm{C}$ for $12 \mathrm{~h}$.

\section{Spectroscopic characterizations}

The morphology and microstructure of the samples were characterized by field emission scanning electron microscopy (FE-SEM, JEOL 6701F), transmission electron microscopy (TEM, JEOL 2010). X-ray diffraction (XRD) spectrometry was preformed on a Rigaku D/max-2500 diffractometer with $\mathrm{Cu} \mathrm{K} \alpha$ radiation ( $\lambda$ $=1.5418 \AA$ ) at $40 \mathrm{kV}$ and $30 \mathrm{~mA}$. XPS was measured with an ESCALab220i-XL electron spectrometer (VG Scientific) using $300 \mathrm{~W} \mathrm{Al} \mathrm{K} \alpha$ radiation. Fourier transforms infrared spectrometry (FT-IR, Thermo Fisher Scientific) and Raman spectrometry (DXR Raman Microscope, America) were employed to analyze the surface chemical composition. Thermal gravity measurement was made on a TGA/STA409 PC module with a rising temperature rate of $10{ }^{\circ} \mathrm{C} \min ^{-1}$ from 50 to $1000{ }^{\circ} \mathrm{C}$ under continuous air flow. The specific surface area of the as-prepared products was measured on a Quantachrome Autosorb AS-1 instrument, and the pore size distribution was derived from the desorption branches of the isotherm with the Barrett-Joyner-Halenda (BJH) model. The $\mathrm{pH}$ value was measured using pH meter (Thermo Scientific, Model: 410p-13).

\section{Adsorption experiments}

The solutions containing different concentration of $\mathrm{Pb}(\mathrm{II}), \mathrm{As}(\mathrm{V})$ and $\operatorname{As}(\mathrm{III})$ with 10, 20, 50, 100, 200 and $300 \mathrm{mg} \mathrm{L}^{-1}$ were prepared using $\mathrm{Pb}\left(\mathrm{NO}_{3}\right)_{2}, \mathrm{Na}_{2} \mathrm{HAsO}_{4} \cdot 7 \mathrm{H}_{2} \mathrm{O}$ and $\mathrm{NaAsO}_{2}$ as the source of heavy metal ions, respectively. The initial $\mathrm{pH}$ value of the $\mathrm{Na}_{2} \mathrm{HAsO}_{4}$ and $\mathrm{NaAsO}_{2}$ solution was adjusted to 4 using hydrochloric acid $(0.2 \mathrm{M})$. The time-dependant curves were preformed with the initial ion concentration on $10 \mathrm{ppm}$ and the sample dose on $20 \mathrm{mg}$ per $100 \mathrm{~mL}$. At predetermined time intervals, $8 \mathrm{~mL}$ supernatant solutions were pipetted and filtered through $0.22 \mu \mathrm{m}$ PTFE membranes. For the adsorption isotherms, $5 \mathrm{mg}$ of the mesoporous titanium glycolate was added to $25 \mathrm{~mL}$ of the above solutions under stirring at room temperature. After $12 \mathrm{~h}$, the samples were separated through $0.22 \mu \mathrm{m}$ PTFE membrane and analyzed by inductively coupled plasma-optical emission spectroscopy (Shimazu ICPE-9000) to measure the concentration of metal ions in the remaining solution. The adsorption capacity of the adsorbents was calculated according to the following eqn (1):4,22

$$
q_{\mathrm{e}}=\frac{\left(c_{0}-c_{\mathrm{e}}\right) v}{m}
$$

where $C_{0}$ and $C_{\mathrm{e}}$ represent the initial and equilibrium concentrations $\left(\mathrm{mg} \mathrm{L}^{-1}\right)$ of heavy metals, respectively. $V$ is the volume of the solution $(\mathrm{mL})$, and $m$ is the amount of adsorbent $(\mathrm{mg})$.

\section{Results and discussion}

Spectroscopic characterizations of titanium glycolate. Fig. 1a and $\mathrm{b}$ are representative scanning electron microscopy (SEM) and transmission electron microscopy (TEM) images of the titanium glycolate prepared by hydrothermal method in ethylene glycol solution. As shown in the SEM image of Fig. 1a, the titanium glycolate material shows V-type strip shape with a mean width of $0.4-1.0 \mu \mathrm{m}$ and length of 6.0-10.0 $\mu \mathrm{m}$. Significantly, the special V-type strip shape was never found in reported titanium glycolate nanostructure materials. The titanium glycolate strip took on well-defined multifaceted structure because of the existence of V-type groove, which undoubtedly would increase the specific surface area in favor of adsorption capacity. TEM image shown in Fig. 1b further revealed that the edge of V-type strips is constituted of a large number of nanoparticles. The energy dispersive X-ray spectrum (EDS) is recorded to identify the composition of the as-prepared sample (Fig. S1†), in which $\mathrm{Ti}, \mathrm{C}$, and $\mathrm{O}$ were observed as the main elements, indicating the formation of target titanium glycolate; the crystallographic structure of titanium glycolate is determined by X-ray powder diffraction (XRD), as shown in 

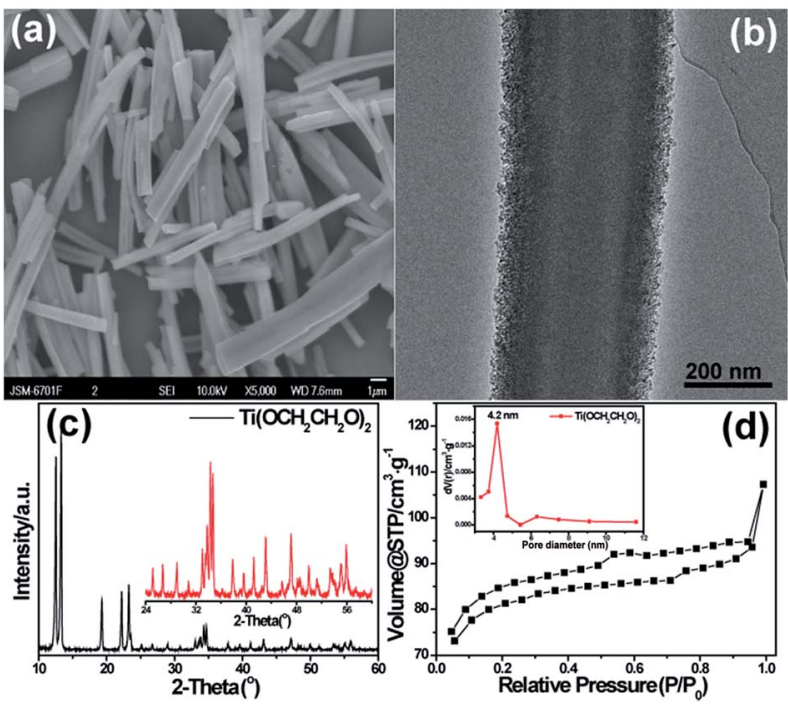

Fig. 1 Representative SEM image (a), TEM image (b), and wide-angle XRD patterns (c) of titanium glycolate; (d) nitrogen adsorptiondesorption isotherm with the pore size distribution curves by the $\mathrm{BJH}$ method (insets) of the titanium glycolate.

Fig. 1c, where the sharp diffraction peaks are mainly ascribed to $C$-center monoclinic titanium glycolate. ${ }^{23}$

The specific surface area of the titanium glycolate is studied by nitrogen adsorption-desorption experiment. As shown in Fig. 1d, the BET surface area is estimated to be $246.5 \mathrm{~m}^{2} \mathrm{~g}^{-1}$, and combining the observed type IV isotherm with a distinct hysteresis loop, it is indicated that the titanium glycolate owns a mesopore structure with the pore size ranging from 3.3 to $5.4 \mathrm{~nm}$ and the average diameter $c a .4 .2 \mathrm{~nm}$ (Fig. 1d inset).

X-ray photoelectron spectroscopy can provide valuable insight into the surface chemical composition of titanium glycolate. The survey XPS spectrum of $\mathrm{Ti}\left(\mathrm{OCH}_{2} \mathrm{CH}_{2} \mathrm{O}\right)_{2}$ in Fig. 2a shows the composition of sample with $\mathrm{Ti}, \mathrm{O}$ and $\mathrm{C}$ elements. As indicated in the insert of Fig. 2a, the two Ti 2p peaks at 458.9 and $464.6 \mathrm{eV}$ correspond to binding energies of $\mathrm{Ti} 2 \mathrm{p}_{3 / 2}$ and $\mathrm{Ti}$ $2 \mathrm{p}_{1 / 2}$, respectively, indicating the presence of a $\mathrm{Ti}(\mathrm{IV})$ oxidation state in titanium glycolate; ${ }^{24}$ the high-resolution XPS of $\mathrm{O} 1 \mathrm{~s}$ in Fig. 2b reveals two well-defined peaks at 531.3 and $532.0 \mathrm{eV}$, which are separately attributed to $\mathrm{Ti}-\mathrm{O}$ and $\mathrm{C}-\mathrm{O}$ species; the broad peak of $\mathrm{C}$ 1s (Fig. 2c) is well-fitted by two sub-peaks with binding energies of 285.2 and $286.2 \mathrm{eV}$, where the dominant peak at $285.2 \mathrm{eV}$ is characteristic $\mathrm{C}-\mathrm{C} / \mathrm{CH}_{n}$, and the other peak is assigned as C-O. ${ }^{25}$ Moreover, survey scans of the $\mathrm{Ti}\left(\mathrm{OCH}_{2} \mathrm{CH}_{2}\right.$ $\mathrm{O})_{2}$ sample further reveals the atom ratio of $\mathrm{Ti}: \mathrm{O}: \mathrm{C}$ being about $1: 4.5: 4.6$, which is accordance to the theoretical value $1: 4: 4$. The somewhat extortionate estimate of $\mathrm{C}$ and $\mathrm{O}$ is believed to be resulted from remnant ethylene glycol and/or the adventitious carbohydrates adsorbed on the sample.

To investigate the thermal-stability properties of the titanium glycolate, TG-DTG analyses were performed in air (Fig. 2d). Referring to strong exothermic peak around $352.8{ }^{\circ} \mathrm{C}$, the weight loss between 200 and $500{ }^{\circ} \mathrm{C}$ on the TG curve is caused by the decomposition of $\operatorname{Ti}\left(\mathrm{OCH}_{2} \mathrm{CH}_{2} \mathrm{O}\right)_{2}$, in which the
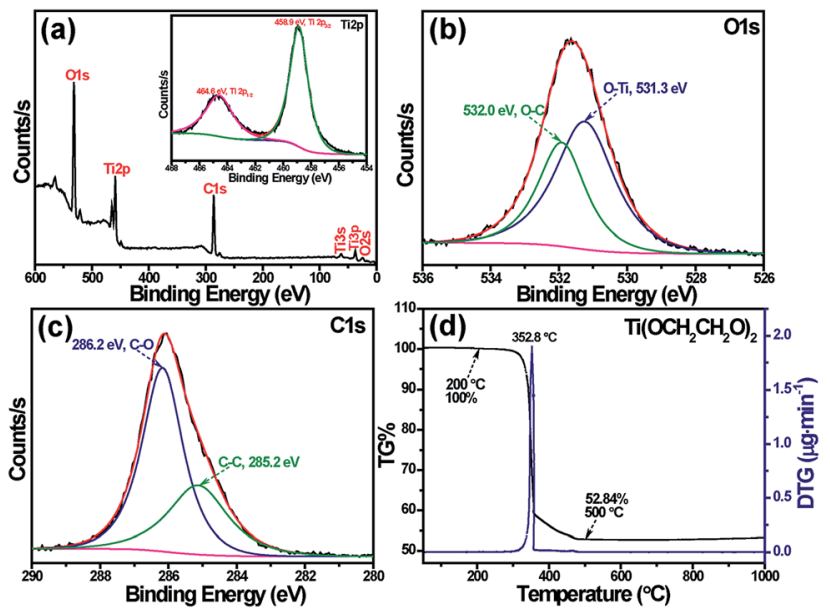

Fig. 2 (a) XPS survey spectrum, and the inset shows a high-resolution XPS spectrum of $\mathrm{Ti} 2 \mathrm{p}$; (b) $\mathrm{O}$ 1s of $\mathrm{Ti}\left(\mathrm{OCH}_{2} \mathrm{CH}_{2} \mathrm{O}\right)_{2}$; (c) $\mathrm{C}$ 1s of $\mathrm{Ti}\left(\mathrm{OCH}_{2} \mathrm{CH}_{2} \mathrm{O}\right)_{2}$; (d) TG and DTG curves of titanium glycolate.

large one step weight loss of $47.16 \%$ is consistent with the calculated value $(47.55 \%)$ from $\mathrm{Ti}\left(\mathrm{OCH}_{2} \mathrm{CH}_{2} \mathrm{O}\right)_{2}$ to $\mathrm{TiO}_{2} \cdot{ }^{26}$

Heavy metal were removed by the titanium glycolate. The high surface area and mesopore structure of the titanium glycolate gave a suggestion to be an excellent candidate for heavy metal removal in water treatments. Based on the previous studies of titanium-based nanomaterials on drinking water treatments, $\mathrm{As}(\mathrm{III}), \mathrm{As}(\mathrm{v})$ and $\mathrm{Pb}(\mathrm{II})$ ions were selected as typical toxic heavy metal ions to examine the efficiency of the titanium glycolate used in water treatments.

The surface charge of a sample is usually an important parameter to assess adsorption behaviour, so the zeta potential of $\mathrm{Ti}\left(\mathrm{OCH}_{2} \mathrm{CH}_{2} \mathrm{O}\right)_{2}$ was firstly measured. Before measurements, the samples were dispersed in deionized water to form a homogeneous solution by ultrasonic followed by continuous stirring for $12 \mathrm{~h}$. The $\mathrm{pH}$ values of the composite were initially adjusted from 2.0 to 10.0 by adding $0.2 \mathrm{M} \mathrm{HCl}$ or $\mathrm{NaOH}$. As shown in Fig. $\mathrm{S} 6, \uparrow$ the point of zero charge $\left(\mathrm{pH}_{\mathrm{pzc}}\right)$ of the $\mathrm{Ti}\left(\mathrm{OCH}_{2} \mathrm{CH}_{2} \mathrm{O}\right)_{2}$ is about 5.15, which means the surface charge of $\mathrm{Ti}\left(\mathrm{OCH}_{2} \mathrm{CH}_{2} \mathrm{O}\right)_{2}$ is positive at $\mathrm{pH}<5.15$, while the surface charge of that is negative at $\mathrm{pH}>5.15$.

Because the different chemical forms of As(III) and As(v) in aqueous solution, the $\mathrm{pH}$ dependence of the titanium glycolate using on $\mathrm{As}(\mathrm{v})$ and $\mathrm{As}(\mathrm{III})$ adsorption is firstly studied. $\mathrm{Na}_{2}$ $\mathrm{HAsO}_{4} \cdot 7 \mathrm{H}_{2} \mathrm{O}$ and $\mathrm{NaAsO}_{2}$ were used to obtain $\mathrm{As}(\mathrm{v})$ and $\mathrm{As}(\mathrm{III})$ solution with $10 \mathrm{mg} \mathrm{L}^{-1}$ of initial arsenic concentrations, and $0.2 \mathrm{~g} \mathrm{~L}^{-1}$ dosage of $\mathrm{Ti}\left(\mathrm{OCH}_{2} \mathrm{CH}_{2} \mathrm{O}\right)_{2}$ is used as adsorbent. As shown in Fig. 3, it is observed that the arsenic sorption behavior by $\mathrm{Ti}\left(\mathrm{OCH}_{2} \mathrm{CH}_{2} \mathrm{O}\right)_{2}$ depends strongly on the $\mathrm{pH}$ values. Obviously, $\mathrm{Ti}\left(\mathrm{OCH}_{2} \mathrm{CH}_{2} \mathrm{O}\right)_{2}$ has a high adsorption ability for $\mathrm{As}(\mathrm{v})$ at $\mathrm{pH}<5$, but the ability reduces rapidly when $\mathrm{pH}$ value being larger than 5. On the contrary, poor adsorbing efficiency for As(III) of $\mathrm{Ti}\left(\mathrm{OCH}_{2} \mathrm{CH}_{2} \mathrm{O}\right)_{2}$ was investigated on low $\mathrm{pH}$ value but good efficiency can be obtained when $\mathrm{pH}>4$ and then keep constant until $\mathrm{pH}=10$.

The $\mathrm{pH}$ dependence of the titanium glycolate adsorbent for $\mathrm{As}(\mathrm{v})$ can be ascribed to the protonation of $\mathrm{Ti}\left(\mathrm{OCH}_{2} \mathrm{CH}_{2} \mathrm{O}\right)_{2}$, 


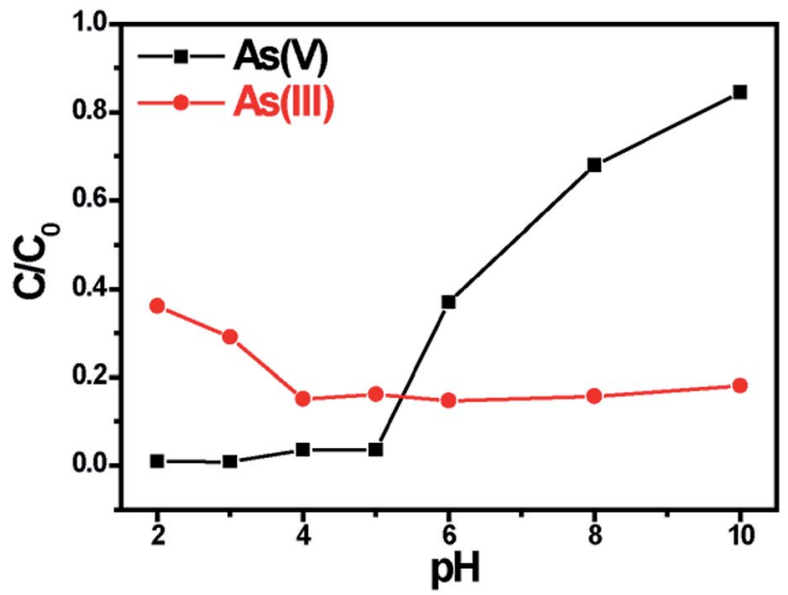

Fig. 3 Adsorption efficiency of $\mathrm{As}(\mathrm{V})$ and $\mathrm{As}(\mathrm{II})$ by titanium glycolate as a function of $\mathrm{pH}$. Experiments were conducted at $\mathrm{pH} 2-10$, with $5 \mathrm{mg}$ samples stirring for $2 \mathrm{~h}$. Initial arsenic concentration: $10 \mathrm{mg} \mathrm{L}^{-1}$, sample volume: $25 \mathrm{~mL}$.

which makes the material to carry positive charges under low $\mathrm{pH}$ condition and naturally adsorb the negative-charged $\mathrm{As}(\mathrm{v})$ of $\mathrm{HAsO}_{4}{ }^{2-} / \mathrm{H}_{2} \mathrm{AsO}_{4}{ }^{-}$ions driven by electrostatic interactions. But along with the $\mathrm{pH}$ value increasing, more and more $\mathrm{OH}^{-}$ions are introduced into the solution that would compete with the $\operatorname{As}(v)$ species to be adsorbed on the titanium glycolate surface so that affect the $\operatorname{As}(\mathrm{v})$ absorption ability of this material. Otherwise, the electrostatic adsorption between $\mathrm{As}(\mathrm{III})$ and $\mathrm{Ti}\left(\mathrm{OCH}_{2}-\right.$ $\left.\mathrm{CH}_{2} \mathrm{O}\right)_{2}$ would never happen since $\mathrm{As}(\mathrm{III})$ does not exist in the anions in water, ${ }^{27}$ leading to weak $\mathrm{pH}$ dependence of the $\mathrm{Ti}\left(\mathrm{OCH}_{2} \mathrm{CH}_{2} \mathrm{O}\right)_{2}$ for $\mathrm{As}(\mathrm{III})$. In fact, it is suggested that the adsorption of As(III) on $\mathrm{Ti}\left(\mathrm{OCH}_{2} \mathrm{CH}_{2} \mathrm{O}\right)_{2}$ follow by means of a coordination interacting mechanism.

The adsorption speed of titanium glycolate for $\mathrm{Pb}(\mathrm{II}), \mathrm{As}(\mathrm{v})$ and $\operatorname{As}(\mathrm{III})$ is investigated, as shown in Fig. 4a, which is undoubtedly one of the most important features for materials using in water treatments. It can be clearly observed that adsorption ability of $\mathrm{Ti}\left(\mathrm{OCH}_{2} \mathrm{CH}_{2} \mathrm{O}\right)_{2}$ for different heavy metal ions is quite different, i.e., the adsorption/desorption reach an equilibrium in $20 \mathrm{~min}$ for $\mathrm{Pb}(\mathrm{II})$, in $30 \mathrm{~min}$ for $\mathrm{As}(\mathrm{V})$ and in $60 \mathrm{~min}$ for $\mathrm{As}(\mathrm{III})$, respectively. If we set the initial ion concentration at $10 \mathrm{mg} \mathrm{L}^{-1}$, the maximum removal efficiency of the $\mathrm{Ti}\left(\mathrm{OCH}_{2} \mathrm{CH}_{2} \mathrm{O}\right)_{2}$ for $\mathrm{Pb}(\mathrm{II}), \mathrm{As}(\mathrm{v})$ and $\mathrm{As}(\mathrm{III})$ is separately $100 \%$, $97.6 \%$ and $89.8 \%$, indicating an excellent performance of this nanomaterial.

The rapid adsorption speed of $\mathrm{Ti}\left(\mathrm{OCH}_{2} \mathrm{CH}_{2} \mathrm{O}\right)_{2}$ for heavy metal ions shows an excellent adsorption kinetic property of this material. A linear form of pseudo-second-order rate model $\left(k_{2}, \mathrm{~g} \cdot \mathrm{mg}^{-1} \mathrm{~min}^{-1}\right)$ was adopted to well fit the experimental data, as shown in Fig. 4b, which suggests a chem-sorption process with the rate limiting step. $^{28}$ Briefly, the pseudosecond-order model is shown as:

$$
\frac{t}{q_{t}}=\frac{1}{k_{2} q_{\mathrm{e}}^{2}}+\frac{1}{q_{\mathrm{e}}} t
$$

where $q_{t}$ and $q_{\mathrm{e}}$ are the amounts of adsorbed heavy metal (mg $\mathrm{g}^{-1}$ ) at time $t$ and at the adsorption/desorption equilibrium
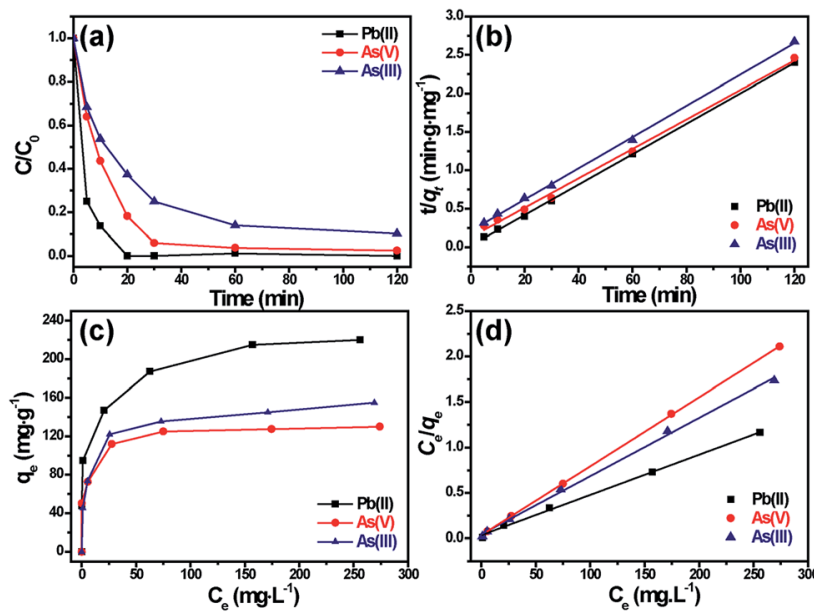

Fig. 4 (a) The concentration change of $\mathrm{Pb}(I), \mathrm{As}(\mathrm{V})$ and $\mathrm{As}(\mathrm{III})$ vs. adsorption time; (b) adsorption kinetics based on the pseudo-secondorder kinetic model for the adsorption of $\mathrm{Pb}(\mathrm{II}), \mathrm{As}(\mathrm{V})$ and $\mathrm{As}(\mathrm{II})$ ions onto the titanium glycolate, in which the initial concentration of metal ions is $10 \mathrm{mg} \mathrm{L}^{-1}$ and the titanium glycolate sample dose is $20 \mathrm{mg}$ per $100 \mathrm{~mL}$; (c) adsorption isotherms; (d) representative Langmuir isotherm of $\mathrm{Pb}\left({ }_{1}\right), \mathrm{As}(\mathrm{V})$ and $\mathrm{As}(\mathrm{II})$ adsorption on the titanium glycolate, with the initial ion concentrations being $10-300 \mathrm{mg} \mathrm{L}^{-1}$ and the sample dose at $5 \mathrm{mg}$ per $25 \mathrm{~mL}$.

time, respectively, $k_{2}$ and $q_{\mathrm{e}}$ can be calculated from the slope and the intercept of the plots of $t / q_{t}$ against $t$, as shown in Table 1 , and the correlation coefficient $\left(R^{2}\right)$ is also shown in the table. Based on this kinetics model, the adsorption rate of $\mathrm{Ti}\left(\mathrm{OCH}_{2}{ }^{-}\right.$ $\left.\mathrm{CH}_{2} \mathrm{O}\right)_{2}$ for $\mathrm{Pb}(\mathrm{II})$ is $c a .6$ times faster than that for $\mathrm{As}(\mathrm{v})$ and 9 times faster than that for As(III).

The adsorption capacity of $\mathrm{Ti}\left(\mathrm{OCH}_{2} \mathrm{CH}_{2} \mathrm{O}\right)_{2}$ for $\mathrm{Pb}(\mathrm{II}), \mathrm{As}(\mathrm{v})$ and $\mathrm{As}(\mathrm{III})$ ions is evaluated using the equilibrium adsorption isotherm. In Fig. $4 \mathrm{c}$, the $C_{\mathrm{e}}$ represents the equilibrium concentration of heavy metal ions $\left(\mathrm{mg} \mathrm{L}^{-1}\right)$ with different initial amounts of the heavy metals from 10 to $200 \mathrm{mg} \mathrm{L}^{-1}$, and $q_{\mathrm{e}}$ is the amounts of adsorbed heavy metal $\left(\mathrm{mg} \mathrm{g}^{-1}\right)$ while the adsorption/desorption process reaching equilibrium. It can be observed that while the initial amount of heavy metal is little, all of the heavy metal ions are adsorbed by $\mathrm{Ti}\left(\mathrm{OCH}_{2} \mathrm{CH}_{2} \mathrm{O}\right)_{2}$, but along with the increasing of the initial concentration of heavy metal ions, the adsorption capacity $q_{\mathrm{e}}$ of $\mathrm{Ti}\left(\mathrm{OCH}_{2} \mathrm{CH}_{2} \mathrm{O}\right)_{2}$ slowly reaches maximum.

In order to explore the adsorption mechanism, two empirical isotherms models, i.e., the Langmuir and Freundlich models, are adopted to analyze the adsorption process of

Table 1 Experimental and calculated $q_{\mathrm{e}}$ values, pseudo-second-order rate constants $\left(k_{2}\right)$, and correlation coefficient values $\left(R^{2}\right)$. The dosage of the $\mathrm{Ti}\left(\mathrm{OCH}_{2} \mathrm{CH}_{2} \mathrm{O}\right)_{2}$ adsorbent is set as $0.2 \mathrm{~g} \mathrm{~L}^{-1}$

\begin{tabular}{lllll}
\hline $\begin{array}{l}\text { Heavy } \\
\text { metal ions }\end{array}$ & $\begin{array}{l}\text { Experimental } \\
\left(\mathrm{mg} \mathrm{g}^{-1}\right)\end{array}$ & $\begin{array}{l}\text { Calculated } q_{\mathrm{e}} \\
\left(\mathrm{mg} \mathrm{g}^{-1}\right)\end{array}$ & $\begin{array}{l}k_{2} \\
\left(\mathrm{~g} \mathrm{mg}^{-1} \mathrm{~min}^{-1}\right)\end{array}$ & $R^{2}$ \\
\hline $\mathrm{Pb}(\mathrm{II})$ & 50.00 & 50.51 & $1.829 \times 10^{-2}$ & 0.9997 \\
$\mathrm{As}(\mathrm{v})$ & 48.79 & 52.16 & $2.876 \times 10^{-3}$ & 0.9961 \\
$\mathrm{As}(\mathrm{III})$ & 44.90 & 49.16 & $1.957 \times 10^{-3}$ & 0.9990
\end{tabular}


Table 2 The maximum adsorption capacity $\left(q_{m}\right)$, equilibrium constant (b), and correlation coefficient values $\left(R^{2}\right)$

\begin{tabular}{llll}
\hline Heavy metal ions & $q_{\mathrm{m}}\left(\mathrm{mg} \mathrm{g}^{-1}\right)$ & $b\left(\mathrm{~L} \mathrm{mg}^{-1}\right)$ & $R^{2}$ \\
\hline $\mathrm{Pb}(\mathrm{II})$ & 225.73 & 0.1253 & 0.9977 \\
$\mathrm{As}(\mathrm{V})$ & 131.93 & 0.2119 & 0.9999 \\
$\operatorname{As}($ III) & 156.01 & 0.1444 & 0.9978
\end{tabular}

$\mathrm{Ti}\left(\mathrm{OCH}_{2} \mathrm{CH}_{2} \mathrm{O}\right)_{2}$ for $\mathrm{Pb}(\mathrm{II})$, $\mathrm{As}(\mathrm{V})$ and $\mathrm{As}(\mathrm{III})$ ions, which are expressed as follow equations:

$$
\begin{gathered}
\frac{C_{\mathrm{e}}}{q_{\mathrm{e}}}=\frac{1}{q_{\mathrm{m}} b}+\frac{1}{q_{\mathrm{n}}} c_{\mathrm{e}} \\
\log q_{\mathrm{e}}=\log k_{\mathrm{F}}+\frac{1}{n} \log C_{\mathrm{e}}
\end{gathered}
$$

where $q_{\mathrm{m}}$ and $b$ are Langmuir constants that represent the maximum adsorption capacity of the adsorbents and the energy of adsorption, respectively; and $k_{\mathrm{F}}$ and $n$ are the Freundlich isotherm constants that represent the adsorption capacity and the adsorption intensity, respectively.

Comparing the fitting results of the two isotherm models with that of experiments, it was found that the adsorption process of $\mathrm{Ti}\left(\mathrm{OCH}_{2} \mathrm{CH}_{2} \mathrm{O}\right)_{2}$ for $\mathrm{Pb}(\mathrm{II}), \mathrm{As}(\mathrm{v})$ and $\mathrm{As}(\mathrm{III})$ ions follow the Langmuir model (Fig. 4d) as no expected linear plot of Freundlich isotherm is observed (Fig. S2 $\dagger$ ). Therefore, the $\mathrm{Pb}(\mathrm{II})$, $\operatorname{As}(\mathrm{v})$ and $\mathrm{As}(\mathrm{III})$ ions adopt a monolayer adsorption on the surface of $\mathrm{Ti}\left(\mathrm{OCH}_{2} \mathrm{CH}_{2} \mathrm{O}\right)_{2}$.

Based on the Langmuir adsorption isotherm, the correlation coefficients, equilibrium constant and maximum adsorption capacity of the as-prepared $\mathrm{Ti}\left(\mathrm{OCH}_{2} \mathrm{CH}_{2} \mathrm{O}\right)_{2}$ were summarized in Table 2, which indicates clearly a high adsorption capacity of $\mathrm{Ti}\left(\mathrm{OCH}_{2} \mathrm{CH}_{2} \mathrm{O}\right)_{2}$ for all the $\mathrm{Pb}(\mathrm{II}), \mathrm{As}(\mathrm{v})$ and $\mathrm{As}(\mathrm{III})$ ions.

To further explore the adsorption mechanism of $\mathrm{Ti}\left(\mathrm{OCH}_{2}-\right.$ $\left.\mathrm{CH}_{2} \mathrm{O}\right)_{2}$ for heavy metal ions, FTIR spectroscopic characterizations of $\mathrm{Ti}\left(\mathrm{OCH}_{2} \mathrm{CH}_{2} \mathrm{O}\right)_{2}$ were performed to understand how the surface species changes before and after heavy metal ion adsorption on the titanium glycolate, as shown in Fig. 5a. For the $\mathrm{Ti}\left(\mathrm{OCH}_{2} \mathrm{CH}_{2} \mathrm{O}\right)_{2}$ sample, the broad band at $3387 \mathrm{~cm}^{-1}$ is ascribed to stretching vibrations of $-\mathrm{OH}$ groups; the bands at 2927 and $2856 \mathrm{~cm}^{-1}$ are assigned to the stretching vibrations of $\mathrm{C}-\mathrm{H}$; the weak band at $1637 \mathrm{~cm}^{-1}$ can be assigned to the hydroxyl deformation mode of the adsorbed water; the band at $1458 \mathrm{~cm}^{-1}$ is the bending vibration of $-\mathrm{CH}_{2}$ and the bands at 1223 and $1059 \mathrm{~cm}^{-1}$ can be ascribed to $\mathrm{C}-\mathrm{C}$ and $\mathrm{C}-\mathrm{O}$ stretching vibration, respectively. As for the four bands at 918, 879, 632 and $596 \mathrm{~cm}^{-1}$, they can be assigned to the characteristic of ethylene glycolate ligands linked to titanium of $\mathrm{C}-\mathrm{O}-\mathrm{Ti}$, and the other three bands at 536, 498 and $442 \mathrm{~cm}^{-1}$ are assigned to the Ti-O-Ti stretching and bending vibrations. ${ }^{23}$

After the heavy metal ion adsorption, it was observed that the IR spectra features largely changed due to the adsorbed species. First, due to the large coverage of heavy metal ions on the surface of $\mathrm{Ti}\left(\mathrm{OCH}_{2} \mathrm{CH}_{2} \mathrm{O}\right)_{2}$, most characteristic peaks of $\mathrm{Ti}\left(\mathrm{OCH}_{2} \mathrm{CH}_{2} \mathrm{O}\right)_{2}$ become weak or even disappear after the heavy metal ion adsorption; secondly, some new spectral bands
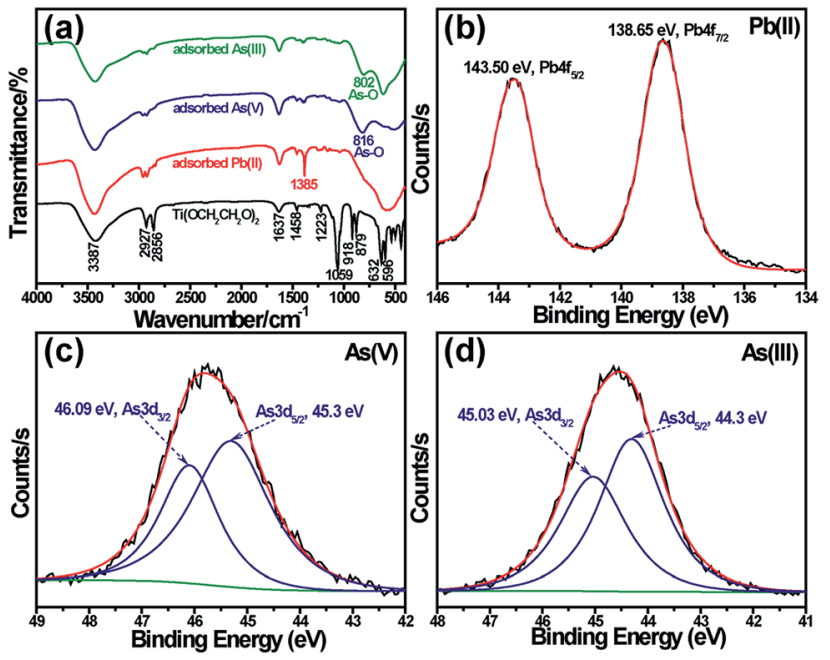

Fig. 5 (a) FTIR spectra of $\mathrm{Ti}\left(\mathrm{OCH}_{2} \mathrm{CH}_{2} \mathrm{O}\right)_{2}$ before and after adsorbing heavy metal ions; high resolution XPS spectrum of (b) Pb(॥) 4f, (c) As(v) $3 \mathrm{~d}$ and (d) As(III) $3 \mathrm{~d}$ on titanium glycolate surface after treating with $200 \mathrm{mg} \mathrm{L}^{-1}$ of $\mathrm{Pb}(॥), \mathrm{As}(\mathrm{V})$ and $\mathrm{As}\left({ }^{\prime \prime}\right)$ aqueous solution at $\mathrm{pH}=4$, respectively.

appear in the spectra corresponding to different heavy metal adsorption, for example, a sharp peak at $1385 \mathrm{~cm}^{-1}$ appears in the spectrum of $\mathrm{Pb}(\mathrm{II})$-adsorbed $\mathrm{Ti}\left(\mathrm{OCH}_{2} \mathrm{CH}_{2} \mathrm{O}\right)_{2}$, which is attributed to the stretching vibration of the adsorbed $\mathrm{NO}_{3}{ }^{-}$ group. ${ }^{29}$ For the $\mathrm{As}(\mathrm{V})$ and $\mathrm{As}(\mathrm{III})$ adsorption, the spectrum separately showed a new peak at $816 \mathrm{~cm}^{-1}$ and $802 \mathrm{~cm}^{-1}$, corresponding to the stretching vibrations of $\mathrm{As}(\mathrm{v})-\mathrm{O}$ and $\mathrm{As}(\mathrm{III})-\mathrm{O}$, respectively. ${ }^{27,30}$ Similar spectral change of $\mathrm{Ti}\left(\mathrm{OCH}_{2} \mathrm{CH}_{2} \mathrm{O}\right)_{2}$ before and after heavy metal adsorption was also observed in Raman spectra (Fig. S3†).

XPS spectrometry is used to further characterize the oxidation state of the adsorbed heavy metals on $\mathrm{Ti}\left(\mathrm{OCH}_{2} \mathrm{CH}_{2} \mathrm{O}\right)_{2}$ nanostructures. Fig. S4 $\uparrow$ shows the full-range XPS spectra of $\mathrm{Ti}\left(\mathrm{OCH}_{2} \mathrm{CH}_{2} \mathrm{O}\right)_{2}$ nanostructures after $\mathrm{Pb}(\mathrm{II}), \mathrm{As}(\mathrm{v})$ and $\mathrm{As}(\mathrm{III})$ adsorptions, and the high-resolution XPS spectrum for the adsorbed heavy metals are shown in Fig. $5 \mathrm{~b}$ to d. In general, $\mathrm{Pb}\left(\mathrm{NO}_{3}\right)_{2}$ shows the $4 \mathrm{f}_{7 / 2}$ peak at $138.5 \mathrm{eV}$, whereas $\mathrm{Pb}$ hydroxides shows corresponding peak at around $137.75 \mathrm{eV}$, so it is obvious that the two XPS peaks at 138.65 and $143.5 \mathrm{eV}$ in Fig. 5b can be attributed to $\mathrm{Pb} 4 \mathrm{f}$ in the adsorbed $\mathrm{Pb}\left(\mathrm{NO}_{3}\right)_{2}$, and this result is consistent with that of FTIR spectrometry. As for the $\mathrm{As}(\mathrm{v})$, the $45.8 \mathrm{eV}$ peak in Fig. $5 \mathrm{c}$ can be deconvoluted into two peaks at $45.3\left(3 \mathrm{~d}_{5 / 2}\right)$ and $46.09 \mathrm{eV}\left(3 \mathrm{~d}_{7 / 2}\right)$, corresponding to As3d(V). Therefore, it is suggested that phys-adsorption is occurred for the above heavy metal ions on titanium glycolate nanostructures.

The XPS curves of Ti $\left(\mathrm{OCH}_{2} \mathrm{CH}_{2} \mathrm{O}\right)_{2}$ samples after absorbing As(III) were analysed carefully as shown in Fig. 5d. Different from the assignment of $\mathrm{As}(\mathrm{v})$, the $44.6 \mathrm{eV}$ peak can be deconvoluted into a pair of peaks at $44.3\left(3 \mathrm{~d}_{5 / 2}\right)$ and $45.03 \mathrm{eV}\left(3 \mathrm{~d}_{7 / 2}\right)$, which can be assigned to $\mathrm{As}(\mathrm{III})-\mathrm{O}$ and $\mathrm{As}(\mathrm{V})-\mathrm{O} .^{31-33}$ This indicates that there are $\mathrm{As}(\mathrm{v})$ to appear on the surface of the mesoporous $\mathrm{Ti}\left(\mathrm{OCH}_{2} \mathrm{CH}_{2} \mathrm{O}\right)_{2}$ nanomaterials, which probably resulted from the oxidization of a part of As(III). In addition, 
there are a large number of hydroxyl groups on the surface of the mesoporous $\mathrm{Ti}\left(\mathrm{OCH}_{2} \mathrm{CH}_{2} \mathrm{O}\right)_{2}$ (Fig. 5a), which contribute to the effective adsorption through the coordination reaction between $-\mathrm{OH}$ and $\mathrm{As}(\mathrm{III})$ in aqueous solution. Therefore, we can infer that the adsorption of As(III) on the surface of mesoporous $\mathrm{Ti}\left(\mathrm{OCH}_{2} \mathrm{CH}_{2} \mathrm{O}\right)_{2}$ nanomaterials is a complex process involved of both oxidization and coordination reaction simultaneously. Namely, the whole adsorption process includes the adsorption of As(III) directly onto $\mathrm{Ti}\left(\mathrm{OCH}_{2} \mathrm{CH}_{2} \mathrm{O}\right)_{2}$, the oxidation of $\mathrm{As}(\mathrm{III})$ to $\mathrm{As}(\mathrm{v})$ and adsorption of $\mathrm{As}(\mathrm{v})$ onto $\mathrm{Ti}\left(\mathrm{OCH}_{2} \mathrm{CH}_{2} \mathrm{O}\right)_{2}$.

Besides of FTIR and XPS, SEM, TEM, EDS and element mapping are also performed to characterize the surface species after the $\mathrm{Ti}\left(\mathrm{OCH}_{2} \mathrm{CH}_{2} \mathrm{O}\right)_{2}$ adsorbing heavy metal ions. As shown in Fig. S5, $\uparrow$ SEM images reveal that the structure of the $\mathrm{Ti}\left(\mathrm{OCH}_{2} \mathrm{CH}_{2} \mathrm{O}\right)_{2}$ adsorbent is slightly damaged after heavy metal adsorption, and EDS analysis confirms the composition of adsorbents after heavy metal ion adsorption containing relevant metals. Moreover, TEM and element mapping further demonstrate that the heavy metal ions are uniformly adsorbed on the $\mathrm{Ti}\left(\mathrm{OCH}_{2} \mathrm{CH}_{2} \mathrm{O}\right)_{2}$ surface.

\section{Conclusions}

A novel titanium-based nanomaterial with large surface area deriving from three-dimensional V-type stripe structure was synthesized by a convenient and green technique. The ecofriend material is well characterized by various spectroscopic techniques, and is found to own mesopore structure with surface area as high as $246.5 \mathrm{~m}^{2} \mathrm{~g}^{-1}$. Being an excellent candidate in drinking water treatments, the titanium-based nanomaterial exhibits fast adsorption rates and high removal capacity for multiple typical toxic heavy metal ions such as Pd(II), As(v) and As(III), no matter which form these metal exists, in cation or anion in the water.

\section{Acknowledgements}

This work is supported by National Basic Research Program (No. 2016YFA0202503) and the National Natural Science Foundation of China (No. 21673257, 51672281).

\section{Notes and references}

1 G. Lofrano, M. Carotenuto, G. Libralato, R. F. Domingos, A. Markus, L. Dini, R. K. Gautam, D. Baldantoni, M. Rossi, S. K. Sharma, M. C. Chattopadhyaya, M. Giugni and S. Meric, Water Res., 2016, 92, 22-37.

2 R. P. Schwarzenbach, B. I. Escher, K. Fenner, T. B. Hofstetter, C. A. Johnson, U. von Gunten and B. Wehrli, Science, 2006, 313, 1072-1077.

3 L. Wang, J. Li, Q. Jiang and L. Zhao, Dalton Trans., 2012, 41, 4544-4551.

4 X.-Y. Yu, R.-X. Xu, C. Gao, T. Luo, Y. Jia, J.-H. Liu and X.-J. Huang, ACS Appl. Mater. Interfaces, 2012, 4, 1954-1962.

5 F. Zhao, P. Severson, S. Pacheco, B. W. Futscher and W. T. Klimecki, Toxicol. Appl. Pharmacol., 2013, 271, 72-77.
6 K. Dutta, P. Prasad and D. Sinha, Int. J. Hyg. Environ. Health, 2015, 218, 564-574.

7 P. Kampalanonwat and P. Supaphol, ACS Appl. Mater. Interfaces, 2010, 2, 3619-3627.

8 N. Wu, H. Wei and L. Zhang, Environ. Sci. Technol., 2011, 46, 419-425.

9 X. Yang, X. Wang, X. Liu, Y. Zhang, W. Song, C. Shu, L. Jiang and C. Wang, J. Mater. Chem. A, 2013, 1, 8332.

10 X. Yang, X. Wang, Y. Feng, G. Zhang, T. Wang, W. Song, C. Shu, L. Jiang and C. Wang, J. Mater. Chem. A, 2013, 1, 473-477.

11 H. Lu, Z. Zhu, H. Zhang, J. Zhu, Y. Qiu, L. Zhu and S. Kuppers, ACS Appl. Mater. Interfaces, 2016, 8, 25343-25352.

12 E. Roy, S. Patra, R. Madhuri and P. K. Sharma, Chem. Eng. J., 2016, 304, 259-270.

13 W. Yan, M. A. V. Ramos, B. E. Koel and W.-X. Zhang, J. Phys. Chem. C, 2012, 116, 5303-5311.

14 B. A. Manning, S. E. Fendorf and S. Goldberg, Environ. Sci. Technol., 1998, 32, 2383-2388.

15 L. C. Jones, B. J. Lafferty and D. L. Sparks, Environ. Sci. Technol., 2012, 46, 6548-6555.

16 C. Hu, H. Liu, G. Chen, W. Jefferson and J. Qu, Environ. Sci. Technol., 2012, 46, 6776-6782.

17 I. K. Levy, M. Mizrahi, G. Ruano, G. Zampieri, F. G. Requejo and M. I. Litter, Environ. Sci. Technol., 2012, 46, 2299-2308.

18 F. Zhang, J. Lan, Z. Zhao, Y. Yang, R. Tan and W. Song, J. Colloid Interface Sci., 2012, 387, 205-212.

19 B. Wang, H. Wu, L. Yu, R. Xu, T. T. Lim and X. W. Lou, Adv. Mater., 2012, 24, 1111-1116.

20 T. Wen, Z. Zhao, C. Shen, J. Li, X. Tan, A. Zeb, X. Wang and A. W. Xu, Sci. Rep., 2016, 6, 20920.

21 J. Huang, Y. Cao, Z. Liu, Z. Deng, F. Tang and W. Wang, Chem. Eng. J., 2012, 180, 75-80.

22 V. Rocher, J.-M. Siaugue, V. Cabuil and A. Bee, Water Res., 2008, 42, 1290-1298.

23 D. Wang, R. Yu, N. Kumada and N. Kinomura, Chem. Mater., 1999, 11, 2008-2012.

24 S. S. Thind, G. Wu and A. Chen, Appl. Catal., B, 2012, 111112, 38-45.

25 C. H. Kim, B.-H. Kim and K. S. Yang, Carbon, 2012, 50, 24722481.

26 D. Wang, R. Yu, Y. Chen, N. Kumada, N. Kinomura and M. Takano, Solid State Ionics, 2004, 172, 101-104.

27 T. Yang, M.-L. Chen, L.-H. Liu, J.-H. Wang and P. K. Dasgupta, Environ. Sci. Technol., 2012, 46, 2251-2256.

28 A. K. Bhattacharya, T. K. Naiya, S. N. Mandal and S. K. Das, Chem. Eng. J., 2008, 137, 529-541.

29 J. Gong, T. Liu, X. Wang, X. Hu and L. Zhang, Environ. Sci. Technol., 2011, 45, 6181-6187.

30 C.-Y. Cao, J. Qu, W.-S. Yan, J.-F. Zhu, Z.-Y. Wu and W.-G. Song, Langmuir, 2012, 28, 4573-4579.

31 G.-S. Zhang, J.-H. Qu, H.-J. Liu, R.-P. Liu and G.-T. Li, Environ. Sci. Technol., 2007, 41, 4613-4619.

32 S. Ouvrard, P. de Donato, M.-O. Simonnot, S. Begin, J. Ghanbaja, M. Alnot, Y.-B. Duval, F. Lhote, O. Barres and M. Sardin, Geochim. Cosmochim. Acta, 2005, 69, 2715-2724.

33 R. Li, W. Yang, Y. Su, Q. Li, S. Gao and J.-K. Shang, J. Mater. Sci. Technol., 2014, 30, 949-953. 